\title{
Chapter 3 \\ Enhancing Value Chain Innovation Through Collective Action: Lessons from the Andes, Africa, and Asia
}

\author{
André Devaux, Claudio Velasco, Miguel Ordinola, and Diego Naziri
}

\begin{abstract}
The development community has shown increasing interest in the potential of innovation systems and value chain development approaches for reducing poverty and stimulating greater gender equity in rural areas. Nevertheless, there is a shortage of systematic knowledge on how such approaches have been implemented in different contexts, the main challenges in their application, and how they can be scaled to enable large numbers of poor people to benefit from participation in value chains. This chapter provides an overview of value chain development and focuses on the International Potato Center's experiences with the Participatory Market Chain Approach (PMCA), a flexible approach that brings together smallholder farmers, traders, processors, researchers, and other service providers in a collective process to explore potential business opportunities and develop innovations to exploit them. The PMCA is an exemplary case of South-South knowledge exchange: it was first developed and implemented in the Andes, but has since been introduced, adapted, and applied to different market chains in Africa and Asia, where it has contributed to improved rural livelihoods. The experiences of adjusting and implementing the approach in these different contexts and the outcomes of those interventions, and complementary approaches, are examined in this chapter. Lessons learned from these experiences are shared with a goal of informing the promotion, improvement, and scaling of value chain approaches in the future.
\end{abstract}

\footnotetext{
A. Devaux $(\bowtie) \cdot$ C. Velasco

International Potato Center, Quito, Ecuador

e-mail: a.devaux@cgiar.org; c.velasco@cgiar.org

M. Ordinola

International Potato Center, Lima, Peru

e-mail: cip-incopa@cgiar.org

D. Naziri

International Potato Center, Hanoi, Vietnam, and Natural Resources Institute,

University of Greenwich, Chatham, UK

e-mail: d.naziri@cgiar.org 


\subsection{Introduction}

Agriculture is rapidly changing in developing countries in response to a variety of factors that include enhanced access to technologies, increased urbanization, shifting in diets, improvements in farmers' education and health, institutional and policy reforms, and investments in rural infrastructure. At the same time, the growing number of supermarkets-referred to as "supermarket revolution" (Reardon and Hopkins 2006) — and the smallholder agriculture integration in changing food markets are helping to create new income opportunities and a more dynamic environment; one in which new technologies and agricultural practices can contribute to helping smallholder farmers respond to these changes and associated challenges. Facilitating sustainable access to high-value markets can enable poor farmers to increase their incomes, making it an effective strategy for reducing poverty (Wiggins and Keats 2013). But those farmers are often at a disadvantage when it comes to producing for and doing business in high-quality food chains and ensuring compliance to both public and private standards (Henson and Humphrey 2010), given their limited access to financial and other services, and their largely poor organizational capacity for collective marketing. Furthermore, their market connections are mostly informal and characterized by high levels of distrust, uncertainty, and transaction costs. This is particularly true for perishable crops, such as potatoes, which are grown on small farms in mountainous areas. For agricultural research to benefit such farmers and make value chains more inclusive, it must be complemented by other efforts to improve the regulatory environment, alleviate resource constraints, and build local capacity to respond to evolving technological and economic challenges and opportunities. It may also be necessary to act to influence the incentives and constraints faced by market actors, so that they can communicate more effectively with farmers and establish mutually beneficial and enduring business relationships.

There are clear signs that agro-industries are having a significant impact on economic development and poverty reduction globally, both in urban and rural communities (FAO 2013). Despite the risks associated with high-value markets, changes in and around the agri-food sector can contribute to the development of better support services for farmers, such as technology, extension, and financial products. There is evidence that small producers with access to technical support services are more willing to adopt new technologies and make investments to take advantage of emerging market opportunities (Royer et al. 2016).

Traditionally, different organizations have designed and implemented different types of interventions in agriculture and associated markets. While public agricultural research and extension programs have focused mainly on increasing agricultural production and productivity, nongovernmental organizations (NGOs) and other entities have focused on commercialization and the development of inclusive value chains. The impact of interventions in these areas has primarily been constrained by the lack of holistic approaches that address the challenges and opportunities along the value chain while taking into consideration the needs and capacities 
of different value chain actors, from input suppliers to farmers, agro-industries, and consumers. Accordingly, development practitioners have progressively introduced the so-called innovation system approaches which bring together different value chain stakeholders in recognition of the fact that systematic change occurs through the interactions of multiple actors — both individual and institutional—and sources of agricultural knowledge and innovation (Biggs 2008; Schut et al. 2016). However, the practical application of agricultural innovation systems and inclusive value chain approaches - and in particular the integration of these two approaches - is a challenge. This has been documented by studies, such as those presenting the results of recent work by the CGIAR ${ }^{1}$ consortium and partners in Africa, Asia, and Latin America, in which the opportunities arising from new and expanding markets for agricultural products are analyzed and the challenges for smallholder participation in these markets, and benefits derived from participation, are identified (Devaux et al. 2016). In Latin America, Devaux et al. (2009) present the case of the Papa Andina Initiative in the Andes, which used collective action to promote innovation in the market chain through two approaches: The Participatory Market Chain Approach (PMCA) (Devaux et al. 2009) and Innovation Platforms (Thiele et al. 2011 b). Both approaches sought to promote the interaction of small-scale potato producers with market actors and agricultural service providers, with a goal of establishing alliances and contractual agreements in response to new market opportunities.

This chapter offers some perspectives on value chain development and presents the experiences of the International Potato Center (CIP) with the PMCA. This approach, originally developed to increase competitiveness and improve the livelihoods of small-scale potato producers in the Andes, has proved useful in other market chains and in other parts of the world, such as East Africa and Asia. The chapter unfolds as follows. We first present the experiences of implementing the approach in the Andes, and the adjustments that have been made to it, while analyzing factors that have influenced its implementation. We then describe and analyze the experiences of replicating and validating the approach in different contexts and regions. Finally, we discuss the lessons learned in order to inform the design of interventions that use the PMCA approach as a research for development tool and provide insights for its replication and adaptation elsewhere.

\subsection{General Concepts of Value Chain Development}

The term "value chain" is used in different ways in literature. In this chapter, by "value chain" we refer to a set of actors that interact to transform inputs and services into products with attributes that consumers are willing to buy. The debate surrounding value chains in recent years has been about understanding the changes that

${ }^{1}$ CGIAR is a global research partnership for a food-secure future (http://www.cgiar.org/) 
take place in some rapidly evolving markets for agricultural products, the consequences of these changes for the poorest actors in the market (specifically small producers and small-to-medium-sized companies), and effective alternatives that governments, development organizations, and the private sector can provide to support those value chain actors. Millions of people with low-incomes-a large portion of them women - participate in agricultural value chains as producers, traders, processors, and retailers (Fig. 3.1). Many millions more, including the majority of the poor in the developing world, participate in agricultural value chains as workers or consumers. Improving the performance of agricultural value chains can thus benefit a large number of people (Reardon and Timmer 2012; Reardon et al. 2012).

We refer to "value chain development" (which we abbreviate as VCD hereafter) as a type of intervention aimed at reducing poverty through improved links between companies, urban dwellers and rural producers. It has been defined as "A positive or desirable change in a value chain to extend or improve productive operations and generate social benefits: poverty reduction, income and employment generation, economic growth, environmental performance, gender equity and other sustainable development goals" (UNIDO 2011). From this perspective, many development agencies, donors, and governments have adopted the value chain approach as a key element of their strategies to reduce rural poverty (Humphrey and Navas-Alemán 2010). In contrast to traditional agricultural research and development (R\&D) approaches, which focus on improving the capacities of small producers to increase their productivity or better manage natural resources, the VCD approach challenges $\mathrm{R} \& \mathrm{D}$ organizations to work with diverse actors to understand how a value chain functions and identify mutually beneficial options to improve its efficiency.

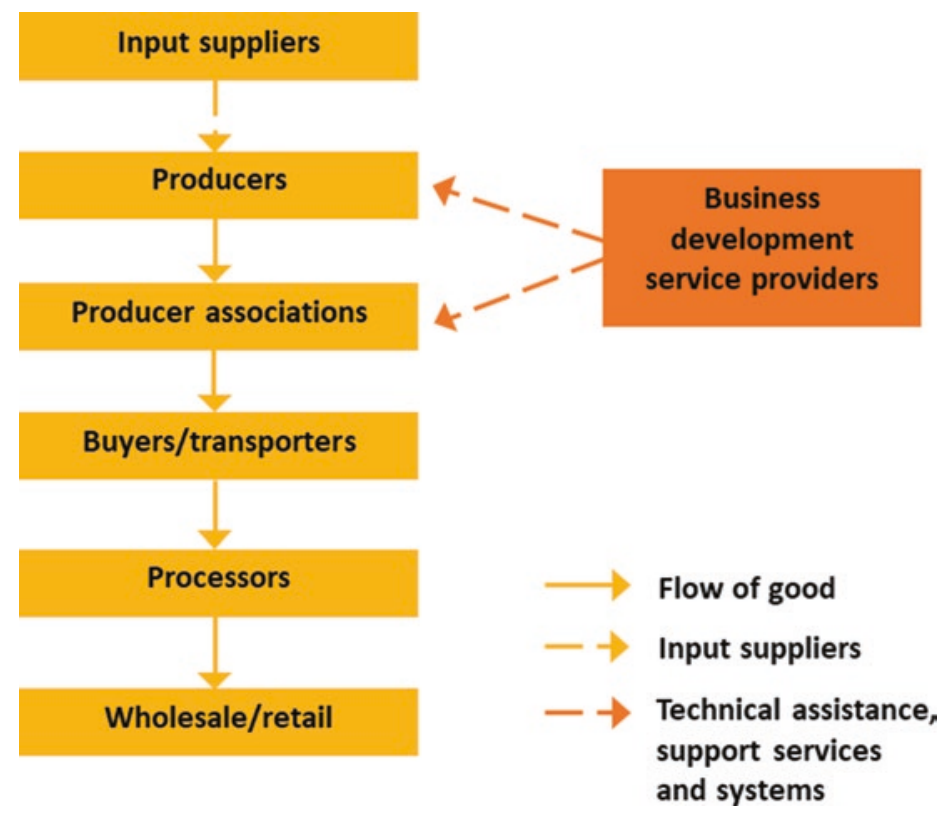

Fig. 3.1 Simple value chain (Devaux et al. 2016) 
While the globalization of markets offers opportunities to market higher value products that simply did not exist before, these markets generally demand much more in terms of business acumen, efficiency and attention to quality and food safety standards than traditional product markets (Reardon et al. 2009). Participation in value chains for more demanding markets requires small-scale producers to deliver a regular supply of products of consistent quality in sufficient quantity at the right time and price. The fulfillment of these conditions requires access to land, inputs, technology, knowledge, organizational capacity, ability, and infrastructure, which may be lacking in some communities or groups of resource-poor farmers. Public policies are also needed to adapt government strategies to different situations and support the participation of smallholder farmers in more dynamic value chains. Smallholders are at a disadvantage compared to medium- and large-scale producers when it comes to taking advantage of these transformations, since they are often located in areas with less private and public infrastructure, are further away from markets, produce comparatively little amounts of products than need consolidation, and have less favorable conditions for high-yielding agriculture.

In this context, CIP, within the framework of its activities in the Andean region, developed a more integrated, participatory approach that combines agricultural, institutional, and value chain innovations while seeking synergies. Called the Participatory Market Chain Approach (PMCA), it is a flexible approach that tries to involve smallscale farmers, market agents (traders, companies, and processors among others), researchers, and service providers in a collective process to identify and explore potential business opportunities that can equitably benefit the diverse actors of a selected value chain (Bernet et al. 2006). It was developed and applied for the first time in Peru, to increase competitiveness in potato market chains, which are important components of local agri-food systems, and to contribute to improving the livelihoods of small farmers. Subsequently, thanks to CIP's global presence, the approach was introduced and adapted together with local organizations that applied it to different market chains in other countries in the Andes, Africa, and Asia, in an example of South-South knowledge exchange. The PMCA is most effective when it is implemented as part of a comprehensive strategy that includes support to farmers' organizations, business development, policy change, and public advocacy. CIP spearheaded the development of the PMCA and has supported the development of local capacities needed to facilitate successful innovation processes (Devaux et al. 2013).

\subsection{The Participatory Market Chain Approach: Origin and Characteristics}

The regional initiative known as Papa Andina (Andean Potato) was implemented from 1999 to 2010 to strengthen the capacity of R\&D organizations in Bolivia, Ecuador and Peru with the overall objective of increasing competitiveness and improving the livelihoods of small-scale potato producers (Devaux et al. 2011). 
In 2002, CIP social scientists working in the Papa Andina program and the Potato Innovation and Competitiveness Project in Peru (INCOPA) ${ }^{2}$ began to experiment with a participatory approach known as Rapid Appraisal of Agricultural Knowledge Systems (RAAKS) (Engel and Salomon 1997). This approach brings together diverse stakeholders in a participatory process to stimulate collective learning, foster trust, and promote innovation. Papa Andina used RAAKS to identify market opportunities involving small-scale farmers, together with other value chain actors, researchers, and service providers.

The participation of traders, supermarkets, food processors, and chefs in a process of research for development was a radical break from previous participatory R\&D efforts, which had been limited to researchers and farmers. Many researchers felt-and some still do-that working with market agents could distract research for development scientists from their focus, which was solving farmers' production problems. When the interventions were implemented, additional steps were added to RAAKS for the development of new products, resulting in a new approach, the PMCA, which was implemented in Peru and then validated in Bolivia in 2003. In subsequent years, this approach was applied in different contexts and thoroughly documented (Ordinola et al. 2009; Devaux et al. 2011).

The PMCA involves the individuals participating in a market chain and service providers, public and private, that support the chain-such as NGOs, financial services providers, development professionals, and researchers-in a facilitated process for identifying and developing innovations to exploit market opportunities. Those innovations can be technological, commercial, or institutional. The PMCA was conceived to be implemented in three phases that last between 9 and 18 months, according to the public and private context and the actors involved (Bernet et al. 2006; Antezana et al. 2008). However, when applied in different contexts, it became apparent that various activities might be required to consolidate progress in strengthening the relationships between the market chains' actors and follow up on technical and commercial innovations after the conclusion of the three phases.

\section{The PMCA's phases (Fig. 3.2):}

- Phase 1. Getting to know market chain actors and their activities through an assessment. The PMCA is initiated by an R\&D organization that takes the lead in selecting the market chain in which it will work, identifying potential R\&D partners and conducting exploratory and participatory diagnostic research on the chain. This phase, which can last from 2 to 4 months, concludes with a public event to discuss the assessment's results, generate ideas for possible innovations and motivate the actors of the market chain and service providers to participate in Phase 2.

\footnotetext{
${ }^{2}$ The INCOPA project, managed by CIP with support from the Swiss Agency for Development and Cooperation, was created to improve potato value chain competitiveness in Peru, with an emphasis on native potatoes grown by smallholder farmers in Andean highlands.
} 
Objective per Phase

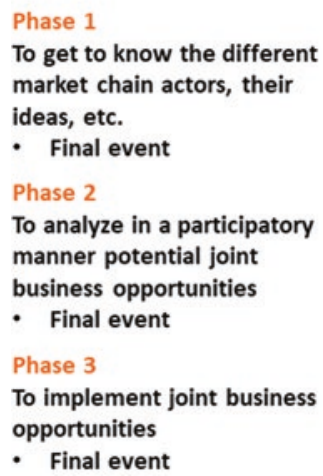

Role of Facilitator

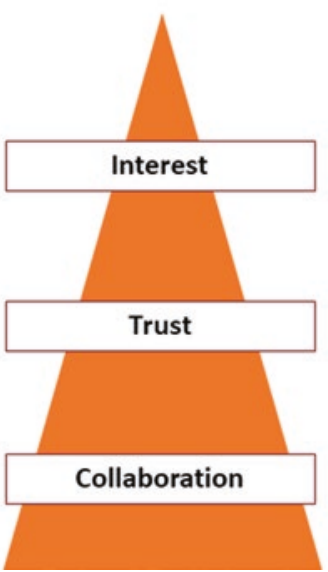

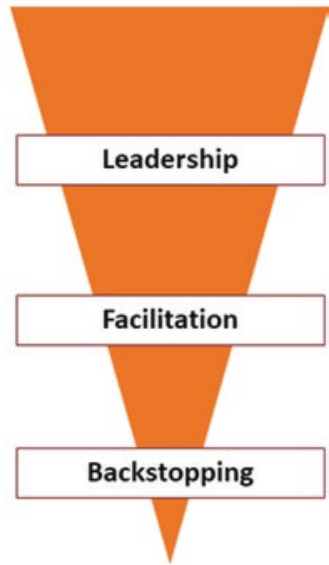

Fig. 3.2 The structure of the methodology: the three phases of the PMCA (Source: Bernet et al. 2006)

Phase 2. Joint analysis of potential market opportunities and innovations needed to take advantage of them. Representatives of participating $R \& D$ organizations facilitate the exploration and analysis of potential market opportunities. Actors of the value chain and service providers are organized in thematic groups that meet between 6 and 10 times to analyze potential opportunities, including thorough technical or market studies. A second public event takes place at the end of Phase 2 to discuss prioritized business opportunities and to encourage new stakeholders, with the appropriate knowledge and complementary experience, to join Phase 3.

Phase 3. Joint development of innovations. During this final phase, the group focuses on the development, market testing, and launch of specific innovations. This may require work in specialized areas such as processing, packaging, labeling or branding tests. Companies increasingly play a leading role in this phase. The PMCA exercise closes with a third public event in which the market innovations developed are presented to a wide selection of stakeholders such as public officials, potential donors, policy makers, decision makers from the private sector (supermarkets, processors, etc.), the public and representatives of the media.

Experiences show that the implementation of the PMCA can deviate from the orderly sequence of phases described above. While some groups have dissolved before producing any useful innovation, others have advanced and launched costeffective innovations during Phase 2. Some groups have also continued to interact and generate innovations years after the conclusion of the PMCA exercise. 


\subsection{Examples of Value Chain Intervention Implemented in Several Geographies}

Since the PMCA was developed, it has been adapted and applied to foster innovation in varied value chains in different countries, including the following:

- Potatoes in Bolivia, Peru, Ecuador, and Indonesia

- Dairy products in Bolivia

- Organic coffee in Peru

- Yams in Colombia

- Sweetpotatoes, tomatoes, and peppers in Uganda

- Potatoes, sweetpotatoes, bananas, and cassava in Uganda

- Aquaculture in Nepal and Bangladesh

- Amazonian fruits in Bolivia

- Fruits and vegetables in Nepal

- Organic and traditional products (e.g., home-made pasta, goat cheese, nuts, honey, mushrooms, tea, and dried fruits and vegetables) in Albania

Only a few of these applications have been well documented and evaluated. In the following sections, we analyze concrete examples of applications of the PMCA in interventions for which there is sufficient published information (Table 3.1).

\subsubsection{Peru's Native Potato Revolution}

From 2001 to 2010, more than 20 public organizations, NGOs and companies collaborated on the INCOPA project, within the framework of the Papa Andina regional initiative. The project focused on both commercial potato varieties and the

Table 3.1 Experiences with the PMCA around the globe

\begin{tabular}{l|l|l|l}
\hline Experience & Product/s & Country/ies & Principal sources \\
\hline $\begin{array}{l}\text { (1) Peru's native potato } \\
\text { revolution }\end{array}$ & Potato & Peru & $\begin{array}{l}\text { Ordinola et al. (2009, 2013, } \\
\text { 2014), Horton and } \\
\text { Samanamud (2013) }\end{array}$ \\
\hline $\begin{array}{l}\text { (2) PMCA experiences in } \\
\text { different value chains in } \\
\text { the Andes }\end{array}$ & $\begin{array}{l}\text { Coffee, milk, yam, } \\
\text { and potato }\end{array}$ & $\begin{array}{l}\text { Peru, Bolivia, } \\
\text { Colombia }\end{array}$ & Horton et al. (2013c) \\
\hline $\begin{array}{l}\text { (3) The revalorization of } \\
\text { native potatoes in Ecuador }\end{array}$ & Potato & Ecuador & $\begin{array}{l}\text { Montesdeoca et al. (2013), } \\
\text { Montesdeoca (2016) }\end{array}$ \\
\hline $\begin{array}{l}\text { (4) Building capacity for } \\
\text { innovation in Ugandan } \\
\text { value chains }\end{array}$ & $\begin{array}{l}\text { Potato, sweetpotato, } \\
\text { tomato, and hot } \\
\text { peppers }\end{array}$ & Uganda & $\begin{array}{l}\text { Mayanja et al. (2012, 2013), } \\
\text { Horton et al. (2010) }\end{array}$ \\
$\begin{array}{l}\text { (5) The PMCA and } \\
\text { Farmer Business Schools } \\
\text { in Indonesia }\end{array}$ & $\begin{array}{l}\text { Potato, sweetpotato, } \\
\text { vegetables, coffee, } \\
\text { and cattle }\end{array}$ & $\begin{array}{l}\text { Indonesia, } \\
\text { Philippines }\end{array}$ & $\begin{array}{l}\text { Horton et al. (2013a, b), } \\
\text { International Potato } \\
\text { Center (2017a) }\end{array}$ \\
\hline
\end{tabular}


native potato varieties that indigenous farmers in the Andes have traditionally grown and consumed. Its objective was to promote innovations in native potato production and commercialization in order to improve the competitiveness of this value chain for the benefit of the small-scale farmers that produce them. To this end, CIP and partners developed and used the PMCA as an applied research and development approach. INCOPA worked to link small-scale producers of native potatoes with researchers, development professionals, and a range of actors in potato market chains (supermarkets, processors, etc.) to capitalize on the biodiversity of native potatoes and their culinary, nutritional, and cultural attributes. The implementation of the PMCA was complemented by efforts to promote alliances and coordination between value chain actors through innovation platforms, to increase public awareness of the virtues of native potatoes and to support the formulation of policies in support of these chains. The PMCA acted as a catalyst for innovations that- together with different interventions in the technical, institutional and political spheres - triggered commercial, productive, and institutional processes that continue to this day, and contributed to what has been dubbed "Peru's native potato revolution" (Horton and Samanamud 2013).

In Peru, two cycles of the PMCA were implemented. The first application focused on the commercialization of improved potato varieties, whereas the second cycle focused on native potatoes. The exercises included the participation of not only researchers, Ministry of Agriculture officials, and typical market chain actors but also chefs and supermarket managers. This was the first time that such a diverse group met to collaborate on options for promoting the potato in Peru. The "new actors" brought new energy, perspectives, and ideas to discussions that had previously been dominated by R\&D professionals.

The first application of the PMCA, which started in 2002 in Peru, gave rise to the country's first brand of selected fresh potatoes, Mi Papa (My Potato), which was distributed through the wholesale market in Lima. Subsequently, a new organization, CAPAC Peru, was created with the participants to promote the commercialization of high-quality local agricultural products, including potatoes marketed under the $M i$ Papa brand. The second application of the PMCA resulted in two new products made with Peru's native potatoes. T'ikapapa was launched as the first brand of gourmet, fresh native potatoes sold in supermarkets in the Peruvian capital, Lima. Shortly after that, Jalca Chips, an innovative potato chip product made of naturally colored (blue, red, yellow) native potatoes, was launched. Jalca Chips, sold in duty-free shops in Lima's international airport, opened the way for native potatoes into high-value, processed products markets. Both products were sold in grocery stores but were eventually replaced in the market by other brands of better quality using native potatoes, thanks to a process of creative imitation and improvement. Since then, more than 20 comparable native potato products have appeared on the market ranging from the ones produced by small provincial companies to the products of multinational companies, some of which are exported, as illustrated in Fig. 3.3 (Ordinola et al. 2009).

In addition to the new products, important ideas for policy initiatives, advocacy, and awareness campaigns to promote potato consumption emerged during the 


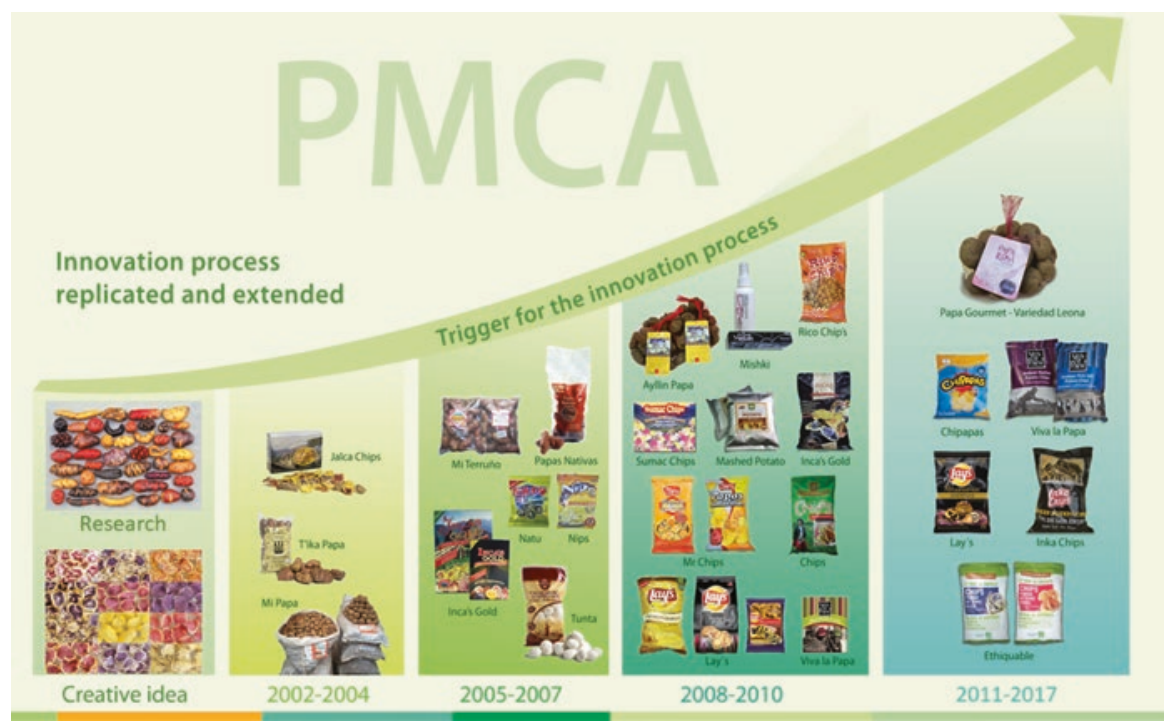

Fig. 3.3 The PMCA as a trigger for innovation in the development of new potato products in Peru. (Source: Updated based on Ordinola et al. 2009)

second cycle of the PMCA. Perhaps the most remarkable one was the creation of a National Potato Day in Peru. It was established in 2005 and has been held annually since then, in both Lima and the provinces. The Minister of Agriculture (MINAGRI) established a special commission to organize the first event, which included organizations that participated in the PMCA. Today this commission continues to function as an institutionalized network and MINAGRI allocates an annual budget for the celebration of National Potato Day, which promotes potatoes to the Peruvian people. This commission supported the efforts of Peruvian government officials to get the United Nations to declare 2008 as the International Year of the Potato. After that proposal was accepted, the commission led numerous outreach activities to promote the celebration of the International Year of the Potato in Peru throughout 2008. The combination of innovations in the market chain, changes in supporting policies, and enhanced public awareness have contributed to improving the image and perceptions of native potatoes in Peru.

Encouraging the big players in the market During the application of the PMCA in Peru, some of the large players in the Peruvian market participated in the initial meetings, but then abandoned the process because they perceived the process timeconsuming and saw few benefits in the short term. As a consequence, the first innovations involved mostly small processing companies and not all of their efforts were sustainable for different reasons, such as quality issues, lack of continuity and failure to position their products. The INCOPA project and its network of public-private collaborators backed the initiatives of the most innovative small entrepreneurs. As these products began to penetrate the markets, the large market players returned to learn about opportunities for developing new potato-based products. They sup- 
ported the creation of institutional arrangements to organize an orderly supply of quality potatoes through commercial arrangements such as contracts to promote good practices that were backed by the project.

These efforts were supported by NGOs that worked in the regions where native potatoes are grown, and that helped producers to organize themselves so to be to supply a product that met the market's quality requirements. The CAPAC Peru platform, ${ }^{3}$ which emerged as an institutional innovation through the PMCA, has supported the native potato value chain by promoting interactions between producers and market agents (Ordinola et al. 2009). With the revamped interest of bigger market players led to the creation of an array of new potato-based products and different brands of native potato chips of superior quality, which ranged from the products of multinationals such as Frito Lay and Grupo Gloria to those produced by small provincial companies, in response to market's diverse demands. The PMCA thus "triggered" a process whereby the second and third generation of innovations are often more important than the ones developed during the approach's initial application (Ordinola et al. 2013; Proexpansión 2011). Figure 3.3 illustrates this process.

Measuring impact In the province of Andahuaylas, in Peru's Apurímac Region, a study was implemented to evaluate the initial scope and impact of the INCOPA project's intervention through the CAPAC Peru platform, using the "impact pathway" methodological framework (Maldonado et al. 2011). In this region, INCOPA used the PMCA to promote the exploitation of market opportunities for native potato biodiversity and improvements in the competitiveness of the potato value chain. For this study, 80 producers in the intervention area were selected through stratified sampling (sampling units are grouped by geographical location), and additional 66 farmers in the same areas were identified as a counterfactual group.

The main conclusions of this case study include:

1. Potato producers in the studied area expanded and diversified their commercial relationships, mainly due to greater demand for native potatoes locally and from supermarkets and agribusinesses in Lima;

2. Small producers in the study area managed to develop business skills and improved their post-harvest management to the degree that they enjoyed increased demand from the new markets that they accessed;

3. Potato producers in the target group belong to organizations that maintained relationships and links with institutions which were engaged through the PMCA process and had continued to provide technical assistance and other services that allowed more efficient business operations;

\footnotetext{
${ }^{3}$ Cadenas Productivas Agrícolas de Calidad en el Perú (Quality Agricultural Production Chains), known as CAPAC Perú, was a second-level, social, economic, and technology promotion organization that provided specialized services for the development of production chains for potato and other tubers in Peru.
} 
4. Farmers involved in the project attained higher average incomes through better prices (26\% higher than the control group) and higher sales volumes of potatoes, especially native potatoes.

In a subsequent case study on the participation of potato growers in Peru's central highlands in native potato value chains, Tobin et al. (2016) studied the social differentiation between participants and nonparticipants within communities and the reasons for the inclusion or exclusion of households in the value chain. His findings indicate that participation in value chains is not necessarily beneficial for all small-scale farmers. For such programs to have broad social benefits, policies and other institutional arrangements are needed to minimize the risks associated with participation in such value chains and to provide support for participation in other types of less demanding markets. Since high-value markets often require more investment and assets, they are probably not the most appropriate option for lowerincome households. Horton and Samanamud (2013) indicate that families with less land, less education, less access to credit, and less developed social networks have benefited less from new market opportunities. But despite these shortcomings, the same authors found that the innovation process generated by the PMCA helped to improve the image of native potatoes and link small-scale farmers with sufficient capacity to dynamic urban markets for potato-based products.

If we analyze the development of native potato value chains in Peru, it is clear that the country's economic and policy contexts have been favorable, including government support and beneficial policies, the participation of a committed private sector, a gastronomic sector willing to promote native products, and the support of international donors such as the Swiss Agency for Development and Cooperation, which strengthened the innovation process through training and coaching in the implementation of the PMCA and the development of innovations. This process made it possible to transform a situation in which native potatoes were nothing more than a subsistence food for poor farmers in the Andean highlands, with little prospect of market-oriented agriculture, to one in which they are now recognized as a noteworthy and nutritious Peruvian product that deserves a price premium in urban markets and gourmet restaurants.

More recently, CIP has built upon this achievement with support from the International Fund for Agricultural Development (IFAD) in a project to strengthen innovation to improve the incomes, food security, and resilience of potato producers in Bolivia, Ecuador, and Peru. This initiative complements IFAD's public investment projects in these three countries and has contributed to expanding the PMCA approach in the region. 


\subsubsection{Analysis of PMCA Experiences in Different Value Chains in the Andes}

From 2007 to 2010, the Andean Change Alliance (Alianza Cambio Andino) ${ }^{4}$ evaluated the processes and results of PMCA implementation in VCD interventions in the Andes. Eight applications of the PMCA were initiated under the leadership of professionals at agricultural R\&D organizations in Bolivia, Colombia, Ecuador, and Peru. None of them had previously implemented the approach, but the Alliance provided them with training and backstopping during implementation. Out of the eight cases initiated, five were completed, four of which were analyzed based on the greatest learning potential with the resources available for the study (Horton et al. 2013c). Those cases are:

Case 1. Marketing high-quality coffee in San Martin, Peru

Case 2. Developing and marketing of new dairy products in Oruro, Bolivia

Case 3. Development of new markets for yams in Northern Colombia

Case 4. Conserving and marketing native potatoes in Northern Potosí, Bolivia

A summary of the results achieved and analysis of each case, according to Horton et al. (2013c), follows.

\subsubsection{Case 1. Marketing of High Quality Coffee in San Martín, Peru}

This case study focused on a women's group that took the lead in the development of a local market for locally produced coffee. Members of the group acquired knowledge and skills in coffee processing and marketing and established a new brand of coffee for the local market. Innovations included more careful selection of coffee beans and improvements in roasting, grinding, and packaging. The application of the PMCA motivated the creation of more networks and relationships among the different stakeholders. They participated in a public event to promote the region's coffee in 2010 that attracted local authorities, private sector players, media, and about 500 members of the public. Success in the commercialization of coffee helped to consolidate the women's group and raise its visibility in public and political circles, as well as in fairs and markets for organic products. They now play a more prominent role in the local agricultural system.

\footnotetext{
${ }^{4}$ Alianza Cambio Andino (Andean Change Alliance) was a regional program of cooperation among organizations and businesses in Bolivia, Colombia, Ecuador, and Peru that contributed to sustainable livelihoods in poor communities by improving the participation of small-scale farmers in innovation processes.
} 


\subsubsection{Case 2. Development and Marketing of New Dairy Products in Oruro, Bolivia}

A local foundation, SEDERA, directed and facilitated implementation of the PMCA with the aim of diversifying the production of community dairy plants. SEDERA and a group of local farmers were successful in producing mozzarella cheese that met local quality requirements and was marketed under the brand Vaquita Andina. The PMCA motivated local dairy producers to diversify the types of cheese they produce and to improve the quality and sanitary standards of their product. While the original goal was to sell the new mozzarella cheese to local pizzerias, this did not materialize, mainly due to its relatively high price. Instead, the main consumers were high-income households willing to pay a premium for a locally produced cheese. The product has been sold in a store operated by SEDERA and in some high-end food markets, including a supermarket in Oruro. Although the economic benefits for small producers were limited, SEDERA gained experience in analyzing market chains and facilitating innovation processes and is now using a more marketoriented approach to its development work.

\subsubsection{Case 3. Development of New Markets for Yams in Northern Colombia}

In April 2008, the PBA Foundation facilitated the PMCA's implementation in 7 market chains over a period of 13 months. Some progress was made in improving the marketing of yams, but no new distinctive yam product was developed or marketed. To sell higher quality yams at better prices, small farmers increased plant density and improved the selection and cleaning of harvested tubers. Some shipments of fresh yams to the US were made, but the Colombian farmers faced strong competition from other Caribbean suppliers in that market. Commercial trials of high-quality yam fiber were hampered by a lack of resources for the construction of a pilot plant. In light of the small size of local farmers' organizations, the PBA Foundation worked to establish a regional network of local associations to improve their marketing performance. An unexpected result was the organization of suppliers within the local market to better coordinate the flow of products and stabilize price. The PBA Foundation has now incorporated elements of the PMCA into its portfolio of participatory methods.

\subsubsection{Case 4. Conservation and Commercialization of Native Potatoes in Northern Potosí, Bolivia}

PROINPA and the Center for Agricultural Development (CAD) have worked for years to conserve the biodiversity of potatoes and other Andean crops and to reduce rural poverty in northern Potosí. They facilitated the development of a new product called Miskipapa, which consisted of selected and washed native potatoes sold in meshes. To market Miskipapa, farmers had to improve the sorting and grading of 
their harvested potatoes. Although they expressed interest, there was little support from local government agencies. Miskipapa was sold for 3 years in supermarkets in La Paz and Cochabamba, in the shop of a mining union, two tourist hotels and farmers' markets. However, due to limitations in both supply and demand of native potatoes, the economic benefits for farmers were limited. Nevertheless, greater awareness of the crop's value contributed to renewed efforts to conserve the region's native potato biodiversity. The most significant result was the experience acquired by $\mathrm{CAD}$, which changed its emphasis from enhancing production to promoting market chain innovation.

To analyze the factors that influenced PMCA implementation and results in these interventions, Horton et al. (2013c) used the "Institutional Analysis and Development (IAD) Framework" developed by Ostrom (2005) and modified Devaux et al. (2009) and Thiele et al. (2011a). This framework considers four main groups of factors that can influence the implementation and results of the PMCA:

- Macro context: which includes government policies, socio-economic conditions, and the agro-ecological characteristics of the region that can influence VCD.

- Market chain: biophysical and technological characteristics of the market chain in which the PMCA is being applied.

- Principal actors: attributes of the relevant market chain actors and service providers involved in the PMCA process.

- Rules in use: formal and (mainly) informal norms and customs that govern the behavior of participants.

The macro context The pro-market policies of Colombia and Peru provided a more favorable environment for the use of the PMCA than the policies of the Bolivian government, which emphasize the role of the state and "communitarian socialism." Agro-ecological environments can also have an effect on the implementation processes and results. In the Bolivian highlands, where poverty is very high and production conditions are adversely affected by climatic risks and the reduced use of inputs, there are severe limitations on the implementation of VCD approaches for the reduction of rural poverty.

The attributes of the chain Successful innovation is more likely in some market chains than in others. In the cases involving coffee in Peru and, to a lesser extent, dairy products in Bolivia, it was possible to bring in outside expertise to improve processing. On the contrary, in the cases of native potato and yam, the knowledge base for commercialization and processing was more restricted. One of the reasons was eventually because the participatory process did not involve the required diversity of participants because of the location and the opportunities linked to the value chain selected. Coffee and dairy products also presented more opportunities for processing, branding and product differentiation than potatoes and yams. As mentioned in the previous section, the processing of native potatoes into colorful potato chips has emerged as a viable enterprise that can respond to the demands of urban consumers in Peru and, to a lesser extent, in Bolivia. However, this type of industry is typically based in urban areas and was not considered to be a viable option for the potato farmers in northern Potosi, Bolivia. 
The main actors The cases analyzed enabled the identification of three types of "champions" that can be crucial for the successful implementation of the PMCA, and for the approach's integration into the work of R\&D organizations. The first type of champion is the facilitator who coordinates the group and supports the innovation processes; the second type is a manager/decision maker, who coordinates the VCD intervention and the implementation of the approach, including mobilization of resources; the third is a recognized leader within the market chain. In the first case study, for example, the facilitator, from the NGO Practical Action in Peru, played a key role in identifying and supporting local actors and facilitating the change processes. A senior manager of the NGO also provided strong institutional support. And the leader of the women's group led the development of the new coffee brand and the creation of networks with other actors in the local coffee sector. The leadership and investment capacity of the private sector are also crucial for the ultimate success of efforts to stimulate business innovations.

The rules in use This refers to social customs, norms and rules, both formal and informal, that guide human behavior on a day-to-day basis. It is an important component in the value chains that were analyzed, which were generally characterized by distrust and limited communication and interaction between the different actors in the chain (such as producers, intermediaries, processors and retailers), which of course limits coordination and collaboration. Ethnic and racial divisions and discrimination were notable in the value chains for potato in Bolivia and yam in Colombia, as compared to the coffee chain in Peru, where such divisions were not observed.

The rules in use (or "standard operating procedures") of the R\&D organizations are also important. The PMCA is facilitated by individuals based at R\&D organizations that have their own mandates, program structures, cultures, norms and external relationships. The mandate and culture at public agricultural research organizations can pose challenges for the successful implementation of the PMCA, as these organizations may be reluctant to work with the private entrepreneurs who process and market agricultural products. For example, the implementing organization in Peru, Practical Action, had a strong tradition of working with all sectors, so it easily incorporated the PMCA into its program to develop coffee markets in Peru. This is not always the case with public entities that are more focused on productive and technological issues.

Another important factor for the implementation of the PMCA is the process of training the people who will implement the approach, especially the group facilitators. If not done properly, deviations or failure to implement the approach may occur, as Horton et al. (2013c) documented. To support the training process, a guide for trainers was produced (Antezana et al. 2008).

\subsubsection{The Revalorization of Native Potatoes in Ecuador}

In November of 2008, through the Andean Change Alliance, CIP began collaborating with the Potato Program at Ecuador's National Agricultural and Livestock Research Institute (INIAP), a local NGO, Fundación Marco, and the Small-Scale 
Potato Producers' Consortium (CONPAPA) on the implementation of PMCA in Ecuador, as part of an effort to create market opportunities based on the country's wealth of native potato varieties.

The qualitative assessment in the first phase of the PMCA involved 29 chefs and administrators of restaurants and hotels in different provinces of the country, in order to determine their knowledge and attitudes towards native potatoes and identify market niches. The results showed that these varieties were largely unknown in restaurant and hospitality sectors of the cities, where they could not be found in markets. Nevertheless, the participants agreed that they had an interesting business potential.

The final event of Phase 1 was thus dubbed as a "Meeting to seek for business opportunities in native potatoes," an activity attended by 35 participants that included chefs, farmers, processors, representatives of local NGOs and public officials. Two interest groups were formed in the event: one on culinary research with native potatoes and the other, considering the requirements of hotels and restaurants, focused on the supply of raw materials.

The participation of the chefs was central to the second phase of this PMCA experience to promote and give visibility to native potatoes in Ecuador. That phase culminated in a massive event organized by the Ecuador Gourmet Cooking School to present and share variations of some of the most traditional dishes in Ecuadorian cuisine made with native potatoes. This event raised the visibility of those varieties and subsequent efforts focused on taking advantage of opportunities in niche markets linked to gastronomy.

In the third phase, other restaurants joined the process in order to promote the consumption of native potatoes and visits by chefs to the farms of native potato growers were encouraged. Those who visited farms understood for the first time the reality of the cultivation of those potatoes, in mountainous areas with difficult access, and accepted that native potatoes should fetch a higher price in the market than commercial varieties. Farmers, for their part, had access for the first time to information concerning the quality and timeliness required for supplying potatoes to this type of market.

A year after initiating the PMCA, the Papa Nativa (Native Potato) brand was launched at the final event of the process with the slogan "Discovering the Andean flavor." The product consisted of selected and washed native potatoes in a mesh. The launch included press conferences and food fairs in the framework of the celebration of Ecuador's National Potato Day.

Developing the product as a commercial innovation triggered technological innovations at the farm level (fertilizer application, better seed management, pest management) and in the presentation of potatoes in the market (moving from an unsorted product to a selected one with a brand name). For the CONPAPA farmers' association, this meant raising members' capacities for postharvest handling and commercialization, since they began selling native potatoes in diverse presentations and linked with consumers such as restaurants and supermarkets in urban areas for the first time. 
Although the "Papa Nativa-Discovering the Andean Flavor" brand has not prospered in the market due to supply problems, high transaction costs, and limited demand, the results of the PMCA were important because it showcased native potatoes in markets other than the local highland markets that they had traditionally been limited to. This result captured the attention of the company INALPROCES, which had been promoting high-quality products with social responsibility criteria for several years. Managers of INALPROCES were inspired by CIP's Papa Andina experience with native potatoes in Peru and foresaw interesting business opportunities in the production and sale of potato chips made with colorful native varieties in the Ecuadorian market and abroad.

INALPROCES partnered with INIAP, the Minga Foundation for Rural Action and Cooperation, CONPAPA and CIP's Ecuador office to identify native potatoes adequate for processing that could be produced and supplied by CONPAPA (Montesdeoca et al. 2013). Two colorful varieties obtained by INIAP by crossing selected native potatoes were chosen for the production of quality potato chips: Puca Shungo (Red Heart) and Yana Shungo ${ }^{5}$ (Black Heart). Their main characteristic is the intense reddish or purple coloration in their flesh, which means they are rich in antioxidants, vitamins, and proteins, and differentiates them from traditional potatoes. In 2011, the brand of colorful native potato chips Kiwa was launched, promoted with support from international cooperation programs as a business model for corporate social responsibility. This business model included working in collaboration with a number of local actors to maintain consistent production levels and to ensure a supply of quality seed potatoes. The model also included training services for farmers based on the Farmers' Field Schools methodology. The business model promoted by INALPROCES was so successful from the beginnings that, in 2011, the company's work with Andean potato farmers was recognized as the best Corporate Social Responsibility project in Ecuador by the EcuadorianGerman Chamber of Industry and Commerce. It also won an international Award "Taste 11 Award for Top Innovation of Anuga-2011" in Germany for the native potato chips.

Since its launch on the market, the product has increased its sales in the domestic and export markets, including United States, Europe, and the Middle East (Fig. 3.4). This growth has promoted collaboration between CIP, INIAP, and CONPAPA farmers to carry out activities aimed at promoting the production of quality seed of the two selected varieties, increasing the volumes of their production and planning sales by CONPAPA to INALPROCES.

The development of Kiwa native potato chips is one of the most noteworthy examples of the evolution of the innovation process that, as we noted, continues and evolves long after the PMCA has formally ended. This commercial innovation has also catalyzed a range of technological innovations. For example, to satisfy the demand for seed potatoes of the varieties used in the production of the Kiwa product, these varieties were included in the seed multiplication program of the INIAP

\footnotetext{
${ }^{5}$ See technical data sheet: http://repositorio.iniap.gob.ec/handle/41000/3267
} 


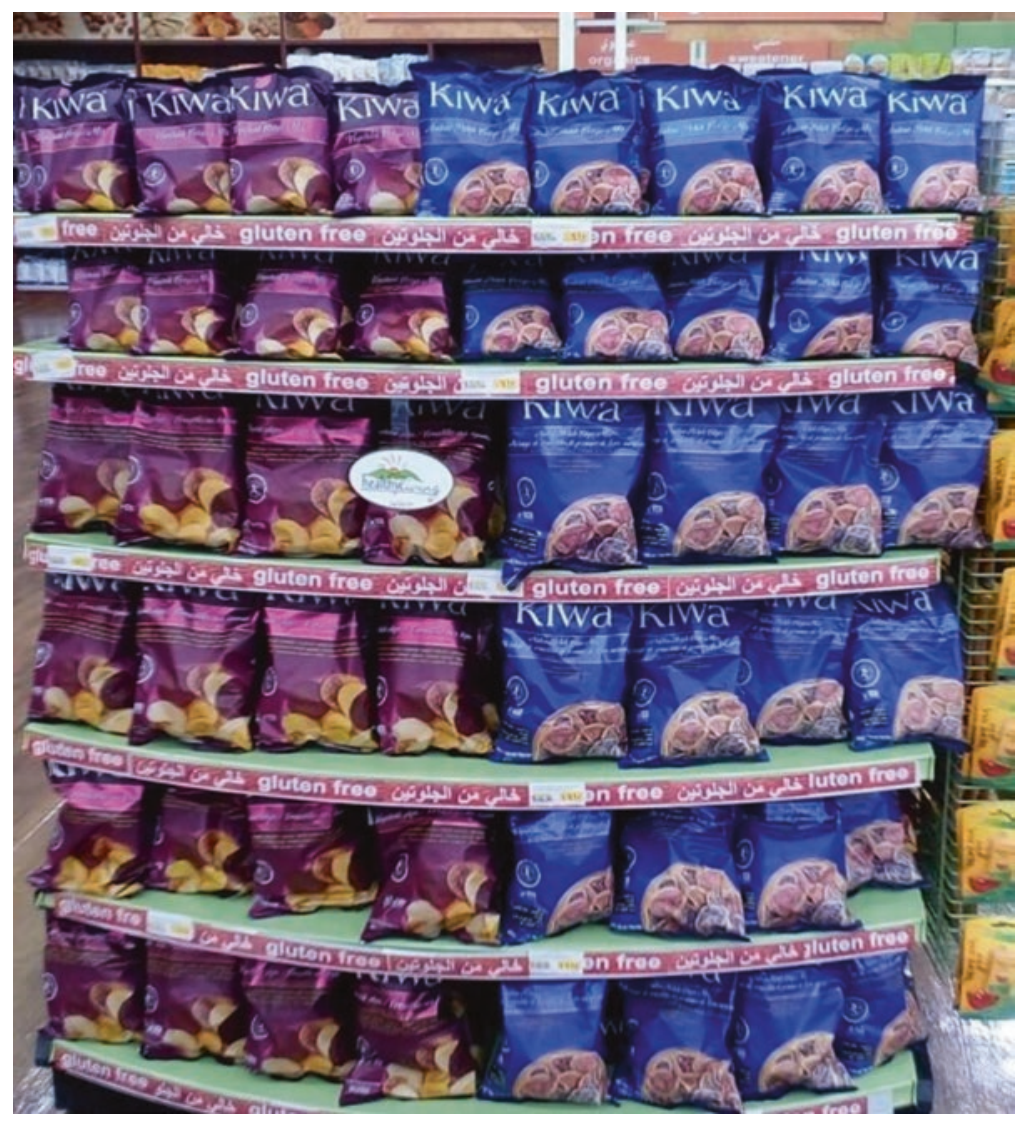

Fig. 3.4 Kiwa potato chips displayed at a supermarket in Saudi Arabia

high-quality seed production greenhouse. However, there are other challenges at the production level, mainly with changes in climate and frost in the Ecuadorian Andes that affected up to $80 \%$ of the production in some years. It is necessary to continue with the selection of varieties that are appropriate for quality processing and more tolerant to weather shocks. In the processing area, it is necessary to find more uses for these potatoes, such as mashed potatoes or frozen French-fry-cut native potatoes for export (Martin Acosta, Kiwa CEO, personal communication).

The Kiwa case is a good example of how market opportunities and desire of social responsible business can be driving forces in the establishment and operation of public-private partnerships for rural development. In particular, the partnership between INIAP, INALPROCES, and CONPAPA generated concrete research demands for the selection of varieties and specific requirements for the provision of high-quality seed and technology transfer services. Through this alliance, CONPAPA has strengthened the business management capacity of associated farmers and their ability to meet the demand of INALPROCES, access technical assistance services 
from public and private suppliers, and respond to other business opportunities. Currently CONPAPA, renamed "AGROPAPA" since 2014, produces certified seed under contract with the Ministry of Agriculture and has increased its customer base of fresh, quality ware potatoes in provincial markets.

\section{Conclusions from This Case}

If we apply the Institutional Analysis and Development (IAD) Framework as used by Horton et al. (2013c) to this case, we gain several insights. Regarding the macro context, it is clear that Ecuador's pro-market policies were not as favorable as Peru's in the case of the Native Potato Revolution. One of the great challenges has been to inspire entrepreneurship in face of a rather limited business mindset. Although Ecuador is one of the countries with the highest records of trademarks and inventions in the Andean region, these rarely translate into actual businesses and commercial uptake. As a result, fewer companies are initiated and fewer employment opportunities are created than in other countries (Wong and Padilla 2017). Furthermore, farmers have limited access to credit for both investment and working capital. As a matter of fact, none of the farmers involved in the PMCA had access to credit and, when necessary, they invested their limited family savings or got personal loans.

Regarding the value chain, native potatoes were unknown by urban consumers and it took a considerable effort to position them in that market as a fresh product and to connect producers with restaurants or potential buyers because there was no appropriate distribution system. Promoting native potatoes as colorful chips has been more successful. Given the smaller size of the Ecuadorian national market compared to Peru, the fact that the product is being placed in international markets has contributed to its success.

In terms of the principal actors, there was support from service providers and chefs in the initial implementation of the PMCA, but apparently, a recognized leader in the native potato chain was missing. When INALPROCESS launched the idea of producing colorful native potato chips, the leadership role was assumed by that company.

If we analyze the rules in use, the native potato value chain was not well organized; there was little communication and limited interaction between the different actors in the chain and service providers. The alliance between the private sector company INALPROCESS and the government institute INIAP was a new experience and it needed to be constructed giving consideration to the norms at INIAP, which has a more technological mandate than marketing and processing. Once the Kiwa native potato chips product was launched, the working model for providing training services and technical support by the company to help farmers respond to market requirements did not work systematically and was not connected with other service providers. For example, there was an unmet demand for a manual of procedures and best practices in crop management, post-harvest treatments, and potato selection, as well as clear and understandable rules and parameters to define the price paid to the farmer for his products. 
Results: The implementation of the PMCA served to showcase native potatoes with the collaboration of the chefs and make them known to a broader public than the rural markets they have traditionally been sold in. The producers were able to meet the quality and supply schedule required by the processing company responding to demanding export potato markets, which has helped them access new market options for their potatoes.

Thanks to INALPROCESS, a colorful native potato chip product was developed which now has a presence in national and international markets. The product accounts today for $20 \%$ of the company's sales. They have been able to sell the Kiwa Native Andean Potato Chips (or Crisps) to retailers all over the world in presentations ranging from vending machine size to Club sizes, to retailers such as Costco in Canada and SnR in Philippines. The company is planning to expand mainly in the USA, the Middle East and Eastern Europe and to move into the organic-certified market (Martin Acosta, CEO Kiwa, personal communication).

\subsubsection{Building Capacity for Innovation in Ugandan Value Chains}

As part of CIP's efforts to facilitate South-South collaboration, the experiences of the PMCA in the Andes were shared with R\&D professionals and actors in the value chains of various agricultural products in Uganda between 2005 and 2007.

The capacity development strategy implemented in Uganda included a series of complementary components. Two cross-learning visits were organized in the Andes for specialists from that country. This exchange generated enthusiasm and interest to apply the methodology in Uganda. Training workshops were organized at the beginning of each phase of the PMCA implementation in Uganda, which allowed members of the facilitating team to practice using tools in real-world situations. Participatory learning and joint decision-making by the facilitating team and thematic teams strengthened teamwork and empowered the participants.

The approach was subsequently validated in potato, sweetpotato, tomato, and hot pepper value chains in Uganda. Eight women from R\&D organizations in the country led the application of the PMCA and facilitated the various meetings of the participants. Specialists from CIP and national entities from Peru and Bolivia provided capacity building and backstopping for the Ugandan team throughout the process (Mayanja et al. 2013; Horton et al. 2010).

Many organizations and individuals played roles in the introduction, validation and refinement of the PMCA in Uganda, including representatives of academic and research institutions, governmental and non-governmental organizations, the private sector and business organizations. Institutions in each of these categories had clear functions. The R\&D institutions were responsible for introducing and facilitating the process of implementing the methodology. They also identified the actors, including service providers, in the market chain that ended up forming the thematic 
Table 3.2 Participants in the first application of the PMCA in Uganda

\begin{tabular}{l|l}
\hline R\&D actors & Market chain actors \\
\hline Potato work group & Tom Cris (processor) \\
\hline Ssemwanga Center & Nyamarogo potato farmers \\
\hline Africa 2000 Network-Uganda & $\begin{array}{l}\text { Uganda National Sweet Potato Producers } \\
\text { Association (UNSPPA) }\end{array}$ \\
\hline Agribusiness Initiative Trust & Merchants from Owino market \\
\hline $\begin{array}{l}\text { International Institute of Tropical Agriculture } \\
\text { (IITA)/Foodnet }\end{array}$ & \\
\hline
\end{tabular}

Adapted from Mayanja et al. (2012)

groups during the implementation of the approach. These different actors worked together to identify and exploit market opportunities. Through this process, innovations were generated.

The potato chain group, for example, was led by the Ssemwanga Center for Agriculture and Food Ltd., a consulting company with members who are also team leaders in the Uganda branch of the Africa 2000 network, the International Institute of Tropical Agriculture (a CGIAR center) and the Agribusiness Initiative Trust. The core team facilitated two thematic groups that were comprised of key actors, such as representatives of farmers' associations, processors and traders, who worked together in an attempt to address the challenges and opportunities identified in the market chain (Table 3.2). The diversity of organizations involved reflects the important role of partnerships in the promotion of innovations for market-driven development. Similarly, different organizations participated in the thematic groups that worked in sweetpotato and vegetable market chains.

The PMCA experience generated a series of results for participants that included the acquisition of new knowledge, skills, social networks and the ability to innovate. The market chain actors generated a series of viable commercial, technological and institutional innovations. The R\&D actors (outside the core team members) and other service providers provided technical assistance, guidance and important links to the industry that contributed to the generation of innovations. Innovations that resulted from the PMCA included packaging and a better brand design for potato chips destined for high value markets, orange-fleshed sweetpotato flour for the local market, and sliced and dried hot pepper for export (Mayanja et al. 2012), some of these market innovations such as the potato chips continue to be produced.

It is important to mention that after the conclusion of the PMCA cycle, several activities were carried out to consolidate the progress in strengthening the relationships between the market chains' actors, follow up on commercial innovations, and promote and institutionalize use of the PMCA by R\&D organizations in Uganda and other countries in the region. All these activities were carried out by the original facilitators, who voluntarily supported the effort after the initial funding for the PMCA had been exhausted. Advice and support was given to market chain actors to help them develop and market new products and present successful proposals for financing. Some of the original facilitators also served as trainers in workshops organized by other development programs in Uganda (Mayanja et al. 2013). 
The PMCA was institutionalized by different entities through the implementation of projects that included the approach and promoted private sector participation. One example is the Mukono Zonal Institute for Agricultural Research and Development, whose director used the PMCA in other value chains, such as pineapple. The NGO VEDCO (Volunteer Efforts for Development Concerns) and local universities also used the approach for innovation in other market chains.

\section{Development of Gender Guidelines for the PMCA in Uganda}

During the different applications of the PMCA in Uganda, CIP researchers came to realize that the approach lacked ways to identify, analyze and address gender and generational differences among value chain actors, which reduced the approach's potential for having a positive impact in terms of ensuring that participants of both genders and all ages have equitable access to opportunities and benefits along value chains. To that end, CIP researchers and partners in Africa and the Andes developed a series of practical tools in recent years to integrate the gender approach into the PMCA's different phases of analysis and intervention. These tools are being tested and validated in projects both in Africa and the Andes Region, and there is an online guide available for their application (Mayanja et al. 2016). The guide seeks to create capacities among the facilitators of the PMCA to carry out a gender analysis to generate a better understanding of the different problems that men and women face in value chain interventions. The results of this analysis guide the development of gender strategies to promote equal opportunities for men and women to benefit from the PMCA.

\section{Conclusions of PMCA Application in Uganda}

The context in Uganda was favorable to the development of the market chain approach. Academic and research institutions, governmental and nongovernmental organizations and the private sector were actively involved in the concrete implementation of the PMCA.

From the beginning, the approach was applied to different chains, due to stakeholder interest, and its implementation was supported by different international cooperation projects. But despite the institutionalization of the approach by some organizations, it is important to recognize the need for adequate financing and institutional arrangements to accompany the work of the facilitators of the innovation process and to be able to follow up on it. After completing the PMCA, it is necessary to continue supporting the development process of emerging innovations and prototypes through business development services to entrepreneurs. Unfortunately, financing mechanisms for this type of services were not considered in the programs of the participating institutions.

The systematic process of training representatives of the R\&D organizations that supported PMCA implementation was key to its development, and subsequent promotion in different value chains. The fact that women from different organizations led the process contributed to adjusting the approach to pay greater attention to gender issues along the chain. A recurring theme in the application of the PMCA in different contexts was the need to provide support to small-scale farmers to improve their productive and business capacity to respond to changing market demands. This is part of a development strategy that should be taken into account in national rural policies. 


\subsubsection{The PMCA and Farmer Business Schools in Indonesia}

Between 2008 and 2009, CIP implemented the PMCA in fresh and processed potato value chains in West Java, Indonesia. Training and support were provided for a team of local implementers. The process resulted in 13 different, duly documented innovation processes, most of which generated new or improved processed products (mainly chips and sandwiches) rather than marketing fresh potatoes (Horton et al. 2013a, b).

During a project review, PMCA implementers identified limited business skills and inefficient farmer organizations as the main limitations that prevented the establishment of more effective links to the market. Farmers had little understanding of market opportunities and inadequate access to much needed market information as price trends and actual demand.

To address such shortcomings, CIP researchers integrated in the PMCA some elements of the Farmers Field School approach (FFS) - a group-based process that had primarily been used to promote integrated pest management by smallholder farmers (Orrego et al. 2009). This resulted in a new VCD approach that was named Farmer Business School (FBS). The FBS is a participatory action-learning process that aim to link groups of farmers to agricultural value chains (International Potato Center 2017a). It differs from other agricultural development approaches in that it focuses on the equitable and effective inclusion of small-scale farmers in value chains, instead of focusing only on farm production activities. The FBS builds farmers' capacity through a series of group learning activities based on real experiences during a farm production/marketing cycle while promoting interaction with other value chain actors. As a tangible outcome of FBS, participants are expected to have actual micro/small enterprises and business initiated or strengthened upon completing the FBS learning process. A FBS guide developed by (International Potato Center 2017b) covers five key issues:

1. Identification of market opportunities

2. Evaluation of market chains

3. Development of market-oriented innovations

4. Development of business plans

5. Provision of business support services

The FBS experience that CIP presented in Indonesia proved useful for strengthening farmers' organizations and building business skills and capacity. It was subsequently adapted by the FoodSTART project to the context of the highlands of the Cordillera region, in the Philippines, primarily to integrate it within the framework of a broader rural development investment project of the International Fund for Agricultural Development (IFAD) called CHARMP2. Between 2012 and 2013, the FBS approach was piloted with 6 groups of farmers (approximately 120 people) dedicated to commercial enterprises based on root and tuber crops, vegetables, coffee and livestock. Following the initial piloting, FBS was scaled to additional 66 groups (approximately 1600 people) between 2014 and 2015, through the 
collaboration between FoodSTART and CHARMP2. It is encouraging that, even after the formal partnership (and any financial and technical support from FoodSTART) ceased, CHARMP2 continued scaling the FBS approach with additional 25 farmers groups (approximately 1000 people). FBS is still the main VCD approach implemented by the Department of Agriculture through CHARMP2 and being FBS graduated has become a pre-requisite for accessing the livelihood assistance from the project (DA-CHARMP2 and CIP-FoodSTART+2018).

Based on the successful experience with CHARMP2, the FBS approach is currently being scaled in Asia by FoodSTART second phase (FoodSTART+) through partnerships with four IFAD investment projects in the Philippines, India and Indonesia. In the framework of FoodSTART+, FBS is being used as catalyst for introducing a number of farming and postharvest innovations to participant farmers groups: these include crop varieties, agronomic practices, processing technologies and marketing strategies needed to develop the new food products demanded by the market.

Comparison of the FFS, FBS and PMCA approaches Farmer field schools, farmer business schools and the participatory market chain approaches all employ the method of learning by doing to improve the well-being of smallholder farming families, but in different ways. The following is a comparative analysis of the three approaches that considers the scope and extent of implementation (Table 3.3).

This comparative analysis indicates that according to results achieved with the FBS in Asia, it could be an appropriate approach when the main challenge is for small-scale farmers' groups to exploit an existing well-defined and clear market

Table 3.3 Comparison of the FFS, FBS, and PMCA approaches

\begin{tabular}{l|l|l|l}
\hline Criteria & FFS & PMCA & FBS \\
\hline $\begin{array}{l}\text { Types of actors } \\
\text { involved }\end{array}$ & $\begin{array}{l}\text { Smallholder } \\
\text { farmers' groups }\end{array}$ & $\begin{array}{l}\text { A diverse set of actors along } \\
\text { the value chain }\end{array}$ & $\begin{array}{l}\text { Focus on smallholder } \\
\text { farmers' groups with } \\
\text { interaction with other } \\
\text { stakeholders in the chain }\end{array}$ \\
\hline Themes covered & $\begin{array}{l}\text { Agricultural } \\
\text { production } \\
\text { techniques }\end{array}$ & $\begin{array}{l}\text { Participation to value chains } \\
\text { and the promotion of } \\
\text { interaction and } \\
\text { collaboration among actors }\end{array}$ & $\begin{array}{l}\text { Farmer organization and } \\
\text { market development themes }\end{array}$ \\
\hline System of focus & Crop system & $\begin{array}{l}\text { Innovation with value chain } \\
\text { actors to promote inclusive } \\
\text { businesses }\end{array}$ & $\begin{array}{l}\text { Agricultural business and } \\
\text { value addition }\end{array}$ \\
\hline $\begin{array}{l}\text { Area of } \\
\text { intervention }\end{array}$ & $\begin{array}{l}\text { Strengthening } \\
\text { farmer } \\
\text { organization }\end{array}$ & $\begin{array}{l}\text { Building “social capital } \\
\text { bridges" to strengthen } \\
\text { interaction and } \\
\text { collaboration among } \\
\text { multiple actors in different } \\
\text { areas of the value chain }\end{array}$ & $\begin{array}{l}\text { Strengthening farmer } \\
\text { organization and innovation } \\
\text { processes for enhanced } \\
\text { participation in value chain }\end{array}$ \\
\hline $\begin{array}{l}\text { Implementation } \\
\text { time frame }\end{array}$ & One crop cycle & $\begin{array}{l}\text { Lasts as long as necessary } \\
\text { innovations in a value chain }\end{array}$ & $\begin{array}{l}\text { Covers one farming and } \\
\text { commercialization cycle }\end{array}$ \\
\hline
\end{tabular}


opportunity. PMCA, on the other hand, has demonstrated to be a preferred approach when the market opportunity is less defined or understood and where there are significant potential benefits for research and innovation in the processing or marketing stages (Devaux et al. 2011). PMCA needs commitment from research organizations while in the case of FBS it is less the case since the engagement with other chain actors and stakeholders is more sporadic. That said, the two approaches can be complementary when combined as the PMCA would contribute to conduct market research and to identify potential market opportunities to be developed. Then FBS can be run to help farmers group to exploit these market opportunities reinforcing farmers' business capacities and developing technological innovations required to respond to these opportunities.

The experience demonstrated the capacity of the actors who led the PMCA implementation process to adapt the approach to contexts and needs and adjust it. In Asia, the implementers developed the Farmer Business School approach to improve farmer's capacities to benefit from market opportunities. As indicated above, the FBS has been integrated into the framework of broader research for development projects, such as FoodSTART, as a tool for developing the farmers' capacity to access more dynamic markets, with also a gender focus, and considering the challenges of climate change. CIP and local partners are now validating the FBS in the Andes in combination with the application of PMCA. It is a process that is still in full development and needs to be further documented.

\subsection{Lessons from Value Chain Approach Applications in Different Contexts}

From the market chain experiences in different contexts described here we can draw lessons that can contribute to improving the design of future VCD interventions that use the PMCA as a collective research and innovation approach. It should be noted that in all of these cases, creative adaptations were made to the protocols set out in the implementation guide (Bernet et al. 2006). Following the analytical framework developed by Horton et al. (2013c), we can highlight the main factors that influenced these adaptations:

- the attributes of the context, which includes the policy environment and institutional framework;

- the attributes of the value chain;

- the characteristics of the participants and the facilitation role of the leading organization;

- the "rules in use" governing behavior and relationships between the value chain actors;

- and the importance of building the capacities of the professionals from R\&D institutions responsible for implementing the approach. 
The interaction of these variables and, especially the external environment of each context determined the implementation strategy and the forces that drove each implementation of the PMCA in the Andes, Asia, and Africa. Each of them was different, as were their scope and size.

Agricultural change creates opportunities for smallholders An important element for the promotion of the PMCA is the ever-growing integration of the agricultural sector into markets and value chains, which increases market opportunities for small-scale farmers. There are more opportunities for them to move beyond the practice of selling directly to rural consumers or traders in local markets to access modern value chains that can open doors to other buyers, including urban traders, processors and supermarket chains. When they have alternatives and the ability to participate in more competitive value chains, few smallholder farmers will limit themselves to local markets; the majority will try to sell to these new players, in order to reap greater benefits (Reardon et al. 2012).

By applying the PMCA, facilitating interactions between farmers and other value chain actors, and conducting market analyses, it is possible to identifying new commercial opportunities and market niches in which small-scale farmers can have a comparative advantage. In the PMCA user guide (Bernet et al. 2006), there is a tool called "impact filter" that provides a rapid, qualitative assessment of the expected impact of different market opportunities for the benefit of small-scale producers, while considering social and environmental factors. This tool allows R\&D organizations to plan and guide interventions more effectively.

A holistic approach like the PMCA represents a new way of doing agricultural R\&D Instead of undertaking research and then trying to transfer the results to farmers, this approach brings together a range of relevant actors-farmers, traders, processors, researchers and service providers - to set priorities and jointly develop innovations that respond better to the demands of the value chain. The approach has made it possible to achieve concrete results under different socioeconomic conditions, despite the fact that most development support for farmers continues to focus on agricultural production. This situation is reflected in the experiences analyzed in this chapter, which demonstrate a shortage of available or accessible services to accompany value chain innovation processes. The inclusive value chain development approach makes it clear that, in the debate on food security, more attention should be paid to post-harvest and value chain interventions, as opposed to focusing only on the farming sector. In the quest to improve food security, value chain efficiency, processing productivity and post-harvest management deserve almost as much attention as approaches to improve farm production.

Innovations take time and cannot always be programmed The PMCA triggers innovation processes that often continue long after the PMCA has formally ended. Second and third generation innovations tend to be even more important than the first ones, developed during the PMCA exercise, as is confirmed by the experiences in Peru, Ecuador and Uganda. However, this requires an investment in services and institutional mechanisms that allow monitoring and supporting innovations that 
arise beyond the life of a specific project. The lack of accompaniment of value chain innovations can be a limitation that reduces the scope of the innovation process. In the case of Peru, for example, the continued support of the Swiss Agency for Development and Cooperation allowed monitoring and accompaniment of innovation process beyond the formal conclusion of PMCA implementation.

Monitoring and evaluation challenges Most of the cases studied lacked a systematic process of monitoring and evaluating value chain innovations. The fact that these processes can take a long time, and that many innovations are developed after the PMCA implementation, with unexpected results, makes it more challenging to do impact analysis. In many cases, the optimal time for evaluating impacts is well after project financing has concluded, when it is not feasible to obtain specific financing for evaluation processes. An implementation guide and impact pathway can be useful guidelines for the implementation and evaluation of participatory approaches such as the PMCA and can serve as a basis for reflection and learning. In research and development projects with limited resources and tight deadlines, it is difficult to justify the time and resources necessary to develop actions and models of change. For this reason, when planning participatory interventions, specific resources should be allocated for the development of actions and models of change that can then be refined and tested by local implementers as the innovation process progresses.

Holistic and participatory approaches such as the PMCA are not easily "scaled" or "transferred" How can the initiatives described here be scaled or replicated better? The answer is not found in a particular or specific arrangement. The processes and approaches, and not so much the forms, are what lead to effective interactions, collaboration between actors and development of a market chain (Wiggins and Keats 2013). What needs to be scaled, in the sense of replication and adaptation, are the habilitation, facilitation and learning processes, supported by a necessary architecture that includes catalysts and leadership, forums and services to analyze and respond to specific problems and, especially, support for the farmers' groups that are organized and trained. The catalysts can be private companies and/ or non-governmental organizations (NGOs). Both have their advantages and disadvantages. In the case of the private sector, the challenge is how to establish an equitable relationship with small-scale producers. In the case of NGOs, they will play the role of catalyst, based on their mission, only as long as they can be financed. To achieve the replication of successful approaches, it is important to promote innovation, learning and dissemination of experiences. To date, investment in learning and dissemination of these experiences has not reached a level comparable to that of the promotion of practical initiatives in the field. The experiences of collaboration with IFAD's investment projects, first in Asia, with FoodSTART, and more recently in South America, with the FIDA-Andes project, coordinated by CIP, has facilitated learning from and diffusion of these experience. In that sense the experience of FoodSTART in the Philippines is innovative and particularly encouraging as, following successful piloting and strengthening of the capacities of the partner's development project staff, the FBS approach has been institutionalized by the Department 
of Agriculture that is replicating and scaling it throughout the region. Similar outcomes are expected from the ongoing second phase of FoodSTART.

The PMCA has proven to be adaptable to a range of contexts Although the PMCA was developed to respond to a specific set of problems with a specific crop in a specific place, subsequent efforts of promotion, exchange of experiences and capacity building have contributed to its successful application to other crops that face different challenges and opportunities in other countries and regions. In the trajectory of its applications in the Andes, Uganda and Indonesia, the PMCA was not simply "transferred" from one place to another. In each case, it was necessary to adapt the approach to local circumstances and needs and to strengthen capacities to promote and accompany innovations.

There is no "one-size-fits-all" solution to the challenges of value chains There is no single factor of success. In each case presented here, a combination of interventions at different levels was needed to address the value chain development processes. A set of policy measures, development programs and technical capacity building for value chain actors are needed to facilitate innovation processes and strengthen effective links to promote the participation of small-scale producers in expanding markets. A comparative study of the variables that influence and determine the adaptation of participatory methodologies such as PMCA in different contexts would allow a better definition of the conditions needed for the replication, adaptation and scaling of these methodologies.

\section{References}

Antezana I, Bernet T, López G, Oros R (2008) Enfoque Participativo en Cadenas Productivas (EPCP): Guía para capacitadores. International Potato Center, Lima, 189 pp

Bernet T, Thiele G, Zschocke T (2006) Participatory market chain approach (PMCA) — user guide. International Potato Center, Lima. http://cipotato.org/publications/pdf/003296.pdf

Biggs S (2008) Learning from the positive to reduce rural poverty and increase social justice: institutional innovations in agricultural and natural resources research and development. Exp Agric 44(1):37-60

DA-CHARMP2 and CIP-FoodSTART+ (2018) Most significant change in the Cordilleras: a pilot evaluation. Department of Agriculture-Second Cordillera Highland Agricultural Resource Management Project and International Potato Center-Food Resilience Through Root and Tuber Crops in Upland and Coastal Communities of the Asia-Pacific, Manila, Philippines

Devaux A, Horton D, Velasco C, Thiele G, López G, Bernet T, Reinoso I, Ordinola M (2009) Collective action for market chain innovation in the Andes. Food Policy 34:31-38

Devaux A, Ordinola M, Horton D (eds) (2011) Innovation for development: the Papa Andina Experience. International Potato Center (CIP), Lima, Peru, 314 pp

Devaux, A., Ordinola, M., Mayanja, S., Campilan, D. and Horton, D. (2013) The participatory market chain approach: from the Andes to Africa and Asia. Papa Andina innovation brief 1 . International Potato Center, Lima, Peru, 4 pp

Devaux A, Torero M, Horton D, Donovan J (eds) (2016) Innovation for inclusive value chain development: successes and challenges. International Food Policy Research Institute (IFPRI), Washington, DC, $529 \mathrm{pp}$ 
Engel P, Salomon M (1997) Facilitating innovation for development: a RAAKS resource box. Royal Tropical Institute, Amsterdam. https://www.kit.nl/sed/ publications/?search $=$ raaks\&q_author $=0 \&$ q_year $=0 \&$ display $=5$

FAO (2013) Agroindustrias para el desarrollo. Roma. http://www.fao.org/3/a-i3125s.pdf

Henson S, Humphrey J (2010) Understanding the complexities of private standards in global agrifood chains as they impact developing countries. J Dev Stud 46(9):1628-1646. https://doi. org/10.1080/00220381003706494

Horton D, Samanamud K (2013) Peru's native potato revolution. Papa Andina innovation brief 2. International Potato Center, Lima, Peru, $6 \mathrm{pp}$

Horton D, Akello B, Aliguma L, Bernet T, Devaux A, Lemaga B, Magala D, Mayanja S, Sekitto I, Thiele G, Velasco C (2010) Developing capacity for agricultural market chain innovation: experience with the 'PMCA' in Uganda. J Int Dev 22:367-389

Horton D, Campilan D, Prasetya B, Gani H, Pakih M, Kusmana (2013a) The PMCA, business development services and farmer business schools in Indonesia. Papa Andina innovation brief 5. International Potato Center, Lima, Peru, 6 pp

Horton D, Campilan D, Prasetya B, Gani H, Pakih MR, Kusmana (2013b) Agricultural market chain development in Indonesia: experiences with the 'Participatory Market Chain Approach', 'Farmer Business Schools', and 'Business development services'. Social Science working document 2013-1. International Potato Center (CIP), Lima

Horton D, Rotondo E, Paz Ybarnegaray R, Hareau G, Devaux A, Thiele G (2013c) Lapses infidelities, and creative adaptations: lessons from evaluation of a participatory market development approach in the Andes. Eval Program Plann 39:28-41

Humphrey J, Navas-Alemán L (2010) Value chains, donor interventions and poverty reduction: a review of donor practice. IDS research report 63. Institute of Development Studies, Brighton

International Potato Center (2017a) Farmer Business School, a climate smart and gender responsive approach. Brief. The International Potato Center-food security through Asian Roots and Tubers (CIP-FoodSTART+), IFAD funded Project, The Philippines, 4 pp

International Potato Center (2017b) Farmer Business Schools in a changing world: a gender responsive and climate smart manual for strengthening farmer entrepreneurship. International Potato Center, Lima. 2 Volumes

Maldonado L, Ordinola M, Manrique K, Fonseca C, Sevilla M, Delgado O (2011) Estudio de caso: Evaluación de impacto de la intervención del proyecto INCOPA/CAPAC en Andahuaylas. CIP, Lima

Mayanja S, Akello B, Horton D, Kisauzi D, Magala D (2012) Value chain development in Uganda: lessons learned from the application of the participatory market chain approach. BANWA 9:64-96

Mayanja S, Akello B, Horton D, Kisauzi D, Magala D (2013) Building capacity for market-chain innovation in Uganda. Papa Andina innovation brief 4. International Potato Center, Lima, 4 pp

Mayanja S, Barone S, McEwan M, Thomas B, Amaya N, Terrillon J, Velasco C, Babini C, Thiele G, Prain G, Devaux A (2016) Prototype guide for integrating gender into participatory market chain approach. International Potato Center, Lima

Montesdeoca L (2016) Reporte trianual 2014-2016 de TRIAS-AGROPAPA-CONPAPA, 14 pp

Montesdeoca L, Acosta M, Quishpe C, Monteros C, Andrade-Piedra J, Pavez I (2013) Rescatando variedades ancestrales: Innovación de las papas nativas en Ecuador. En: "Innovaciones de Impacto, lecciones de la agricultura familiar en América Latina y el Caribe"/Editado por Priscila Enriquez, Hugo Li Pun, San José de Costa Rica. IICA, BID, 224 pp

Ordinola M, Devaux A, Manrique K, Fonseca C, Thomann A (2009) Generando innovaciones para el desarrollo competitivo de la papa en el Perú. Centro Internacional de la Papa (CIP), Lima

Ordinola M, Devaux A, Manrique K, Fonseca C (2013) Innovaciones en la cadena de la papa en el Perú: El valor de la biodiversidad. Leisa, Revista Agroecológica, Volumen 29, número 2, Nuevos mercados, nuevos valores 
Ordinola M, Devaux A, Bernet T, Manrique K, Lopez G, Fonseca C, Horton D (2014) The PMCA and potato market chain innovation in Peru. Papa Andina innovation brief 3. International Potato Center, Lima, 8 pp

Orrego R, Ortiz O, Pradel W, Arévalo A, Barrantes C, Macedo O (2009) Sistematización de la implementación de las Escuelas de Campo de Agricultores (ECAs) en Andahuaylas. Lima (Perú). Centro Internacional de la Papa, Cooperación al Desarrollo-CESAL, Junta de Comunidades de Castilla—La Mancha, 42 pp. ISBN 978-92-9060-371-9

Ostrom E (2005) Understanding institutional diversity. Princeton University Press, Princeton

Proexpansión (2011) Cambios del sector papa en el Perú en la última década: Los aportes del proyecto Innovación y Competitividad de la Papa (INCOPA). Centro Internacional de la Papa, Lima

Reardon T, Hopkins R (2006) The supermarket revolution in developing countries: policies to address emerging tensions among supermarkets, suppliers and traditional retailers. Eur J Dev Res 18:522. https://doi.org/10.1080/09578810601070613

Reardon T, Timmer P (2012) The economics of the food system revolution. Ann Rev Resour Econ 4:225-264

Reardon T, Barrett CB, Berdegué JA, Swinnen JFM (2009) Agrifood industry transformation and small farmers in developing countries. World Dev 37(11):1717-1727

Reardon T, Chen K, Minten B, Adriano L (2012) The quiet revolution in staple food value chains: enter the dragon, the elephant, and the tiger. Asian Development Bank/International Food Policy Research Institute, Mandaluyong City/Washington, DC

Royer A, Bijman J, Bitzer V (2016) Linking smallholder farmers to high quality food chains: appraising institutional arrangements. In: Bijman J, Bitzer V (eds) Quality and innovation in food chains. Wageningen Academic Publishers, Wageningen, pp 33-62. Chapter 2

Schut M, Klerkx L, Sartas M, Lamers D, McCampbell M, Ogbonna I, Kaushik P, Atta-Krah K, Leeuwis C (2016) Innovation platforms: experiences with their institutional embedding in agricultural research for development. Exp Agric 52(4):537-561

Thiele G, Quirós CA, Ashby J, Hareau G, Rotondo E, López G, Paz Ybarnegaray R, Oros R, Arévalo D, Bentley J (eds) (2011a) Métodos participativos para la inclusión de los pequeños productores rurales en la innovación agropecuaria: Experiencias y alcances en la región andina 2007-2010. Programa Alianza Cambio Andino, Lima, 197 pp

Thiele G, Devaux A, Reinoso I, Pico H, Montesdeoca F, Pumisacho M, Andrade-Piedra J, Velasco C, Flores P, Esprella R, Thomann A, Manrique K, Horton D (2011b) Multi-stakeholder platforms for linking small farmers to value chains: evidence from the Andes. Int J Agric Sustain 9(3): $1-11$

Tobin D, Glenna L, Devaux A (2016) Pro-poor? Inclusion and exclusion in native potato value chains in the central highlands of Peru. J Rural Stud 46:71-80

UNIDO (2011) Pro-poor value chain development: 25 guiding questions for designing and implementing agroindustry projects. United Nations Industrial Development Organization, Vienna

Wiggins S, Keats S (2013) Leaping and learning: linking smallholders to markets in Africa. Agriculture for Impact, Imperial College and Overseas Development Institute, London

Wong N, Padilla M (2017) Emprendimiento social para la recuperación de la producción agrícola de patatas nativas de los Andes de Ecuador: Caso KIWA chips. En Experiencias de emprendimiento social en Iberoamérica. Editorial Universidad de Almería. Colección: Libros Electrónicos No 67, pp 77-81 
Open Access This chapter is licensed under the terms of the Creative Commons Attribution 4.0 International License (http://creativecommons.org/licenses/by/4.0/), which permits use, sharing, adaptation, distribution and reproduction in any medium or format, as long as you give appropriate credit to the original author(s) and the source, provide a link to the Creative Commons license and indicate if changes were made.

The images or other third party material in this chapter are included in the chapter's Creative Commons license, unless indicated otherwise in a credit line to the material. If material is not included in the chapter's Creative Commons license and your intended use is not permitted by statutory regulation or exceeds the permitted use, you will need to obtain permission directly from the copyright holder. 